\title{
CURRENT DIVERSITY OF AQUATIC MACROPHYTES IN NIGERIAN FRESHWATER ECOSYSTEM
}

\author{
UKA, U.N.; MOHAMMED, H.A. \& OVIE, S.I. \\ National Institute for Freshwater Fisheries Research, New-Bussa, Niger State Nigeria \\ ukaufere@yahoo.com
}

\begin{abstract}
Uka, U.N.; Mohammed, H.A. \& Ovie, S.I. 2009. Current diversity of aquatic macrophytes in Nigerian freshwater ecsustem. Braz. J. Aquat. Sci. Technol. 13(2):9-15. ISSN 1808-7035. In Nigerian inland waters, eight aquatic plants have been incriminated as weeds. From the current study, the most prevalent of these weeds are water hyacinth and cattail plants. These aquatic weeds, once it invades a water body, not only disrupts the ecology of the systems but adversely affects the sociological, cultural and economic realities of the local communities within the area, especially the artisanal fisher folks. This paper showcases aquatic weeds distribution country wide based on its hydrological areas as well as their controlling methods. These methods, when employed in aquatic weed infested water bodies, will manifestly contribute to the success of approaches geared to solving aquatic weed problems.
\end{abstract}

Keywords: Aquatic macrophytes, Inland waters, Distribution, abundance and Management.

\section{INTRODUCTION}

It is a known fact that about $70 \%$ of the earth surface is covered with water. About $98 \%$ is unconducive for agriculture and drinking. Only extremely small amount are readily available as rivers, streams and lakes. Unfortunately, the available freshwater is not evenly distributed throughout the world. It now rests on man to properly manage this ecosystem. The importance of freshwater bodies as an environmental resource that can be used for the benefit of mankind cannot be overemphasized. These water bodies are important for fisheries, domestic and industrial water supplies among others. Therefore the management of water from its source to utilization is necessary in order to maintain the life functions.

The infestation of freshwater bodies by aquatic weeds influences water management in waterways, rivers, reservoirs and canals. Aquatic weeds are aquatic plants which interfere with the use of water, or in some way constitute a nuisance to man or hazard to human welfare, or growing on a water body where it is not desired (Mitchell,1985). There is an ecosystem imbalance between aquatic plants and other aquatic organisms when the plants invade the system and grows excessively to a nuisance level. The excessive growth of aquatic weed restricts fishing, swimming and recreational activities, causes foul taste and odour of drinking water supplies. It also leads to stunting of fish populations and fish kill due to decomposition (AERF, 2005).

Some alien aquatic plants, for example water hyacinth, have invaded Nigerian freshwater ecosystem causing considerable socio-economic problems. These invasive aquatic weeds affect biodiversity as well as water quality (Uka, 2006). Vegetative reproduction of aquatic plants is well developed that once introduced, they can propagate vigorously in suitable habitat. The uniformity and mildness of aquatic environments as compared to terrestrial ones are also factors that enable the spread of many alien aquatic plants over a wide range. This paper therefore attempts to review the status of aquatic weed infestation in Nigeria and as well discuss components of aquatic plant management plan.

\section{AQUATIC WEED DISTRIBUTION IN NIGERIA}

The distribution of aquatic weeds in Nigeria has basically been influenced by human factors such as environmental manipulation, pollution, expanded use and development of water bodies for irrigation, transportation, recreation and other public purposes (NIFFR, 2002). Other factors include flooding, environmental factor and photosynthetic efficiency. The comprehensive checklist of the aquatic plants in Nigeria is presented in Table 1. The dominant aquatic weeds of the aquatic environment of Nigeria are shown in Table 2. The spatial distribution 
Uka et al.: Distribution of major aquatic weeds in Nigeria inland waters.

Table 1 - Checklist of Nigerian aquatic plants.

\begin{tabular}{|c|c|c|c|}
\hline Family/Species & Number of species & Family/Species & Number of species \\
\hline ALISMATACEAE & 7 & MARANTACEAE & 1 \\
\hline Burnatia enneandra & & Thalia geniculata & \\
\hline Cladesia oligococca & & MENYANTHACEAE & 1 \\
\hline C.reniformis & & Nymphoides indica & \\
\hline Limnnophyton obtusifolium & & MIMOSACEAE & 2 \\
\hline L.fluitans & & Mimosa pigra & \\
\hline $\begin{array}{l}\text { Sagittaria (Lophotocarpus) } \\
\text { guayanensis }\end{array}$ & & Neptunia oleracea & \\
\hline Wiesneria schweinfurthii & & NAJADACEAE & 1 \\
\hline ARACEAE & 1 & Najas horrida & \\
\hline Pistia stratiotes & & NYMPHAECEAE & 4 \\
\hline AMARYLIDACEAE & 1 & Nymphaea lotus & \\
\hline Crinum natans & & N.maculate & \\
\hline APONOGETOMACEAE & 2 & N.micrantha & \\
\hline Aponogeton subconjugatus & & N.guineensis & \\
\hline A.vallisnerioides & & ONAGRACEAE & 6 \\
\hline AZOLLACEAE & 1 & Jussiaea repens Var.diffussa & \\
\hline Azolla Africana & & (Ludwigia stolonifera) & \\
\hline CERATOPHYLLACEAE & 1 & Ludwigia decurrens & \\
\hline Ceratophyllum demersum & & L.erecta & \\
\hline CONVOLVULACEAE & 2 & L.leptocarpa & \\
\hline Ipomoea aquatica & & L.suffruticosa & \\
\hline I.asarifolia & & PARKERIACEAE & 1 \\
\hline CYPERACEAE & 5 & Ceratopteris cornuta & \\
\hline Cyperus alopecuroides & & PODOSTEMONACEAE & 2 \\
\hline C.articulatus & & Tristicha hypnoides & \\
\hline C.exaltatus & & T.trifaria & \\
\hline C. submicrolepis & & POLYGONACEAE & 3 \\
\hline Scirpus cubensis & & Polygonum lanigerum & \\
\hline GRAMINAE (POACEAE) & 12 & P.salicifolium & \\
\hline Echinochloa Colonum & & P.senegalense & \\
\hline E.Pyramidalis & & PONTEDERIACEAE & 4 \\
\hline E.Stagnina & & Eichhornia crassipes & \\
\hline Leersia hexandra & & E.natans & \\
\hline Leptochloa caerulescens & & E.diversifolia & \\
\hline Oryza longistaminata & & Heteranthera callifolia & \\
\hline O.perennis & & POTAMOGETONACEAE & 2 \\
\hline Phragmites karka & & Potamogeton octandrus & \\
\hline Phytachne triaristata & & P.schweinfurthii & \\
\hline Sacciolepis arundinaceum & & RUBIACEAE & 1 \\
\hline Sorghum arundinaceum & & Mitragyna inermis & \\
\hline Vossia cuspidate & & SALVINIACEAE & 1 \\
\hline HYDROCHARITACEAE & 2 & Salvinia nymphellula & \\
\hline Ottellia ulvifolia & & SCROPHULARIACEAE & 1 \\
\hline Vallisnera spiralis & & Limnophila barteri & \\
\hline LEMNACEAE & 3 & SPENOCLEACEAE & 1 \\
\hline Lemna aequinoctialis & & Sphenoclea zeylanica & \\
\hline L. perpusilla & & TRAPACEAE & 1 \\
\hline Spirodela polyrrhiza & & Trapa bispinusa & \\
\hline LENTIBULARIACEAE & 8 & TYPHACEAE & 1 \\
\hline Utricularia reflexa (charoidea) & & Typha australis & \\
\hline \multicolumn{4}{|l|}{ U.gibba subsp.Exoleta } \\
\hline \multicolumn{4}{|l|}{ U.inflexa var inflexa } \\
\hline \multicolumn{4}{|l|}{ U.reflexa (platyptera) } \\
\hline \multicolumn{4}{|l|}{ U.rigida } \\
\hline \multicolumn{4}{|l|}{ U.vitellaris } \\
\hline \multicolumn{4}{|l|}{ U.inflexa var.inflexa (thonningii) } \\
\hline \multicolumn{4}{|l|}{ U.benjaminiana (villosula) } \\
\hline & Total species & & 76 \\
\hline
\end{tabular}

Source: Ita (1994) 
Table 2 - Aquatic vegetation incriminated as weeds in Nigeria.

\begin{tabular}{lc}
\hline \hline Scientific names & Common names \\
\hline Alternanitaera sessile & \\
Azolla Africana & \\
Ceratophyllum demersum & Ceratophyllum \\
Commelina benghalensis & Reed \\
Cyperus spp & Water hyacinth \\
Eichhornia crassipes & \\
Ipomoea aquatica & Wild rice \\
Leersia hexandra & \\
Ludwigia stolonifera & \\
Mimosa pigra & Water lily \\
Nymphea lotus & Nypa palm \\
Nypa fructicans & Water lettuce \\
Pistia stratiotes & \\
Polygonum lanigerum & Water fern \\
Salvinia nymphellula & \\
Scrippus spp & Cattail \\
Typha latifolia &
\end{tabular}

Source: NIFFR (2002)

of aquatic weeds in major inland water bodies found in the hydrological areas is as shown in table 3.

National Institute for Freshwater Fisheries Research estimated the abundance of water hyacinth and other aquatic weeds in Nigeria using Line intercept method (Madsen, 1999). The qualitative rating of aquatic weeds infestation in Nigeria inland waters as shown in table 3 revealed that Eichhornia crassipes (Water hyacinth) and Typha latifolia (Cattail) are the most noxious aquatic macrophytes in our waters and more so, they are widely distributed. In order to manage these invasive aquatic macrophytes, there is the need to fashion out management strategies. These will prevent introduction of nuisance plants, provide an early detection and rapid response programme on the waterbody so that new introductions can be managed quickly at minimal cost, and aid in identifying problems at an early stage. Planning will show case known information as well as knowledge gap.

\section{STRATEGIES FOR WATER HYACINTH MANAGEMENT AND CONTROL}

One of the ways of adopting an effective control and planning is premised on the establishment of the abundance and distribution of the weed infestation. Surveillance trips are usually undertaken first to establish the extent and types of infestation and to decide on the method of control to be used.

In 1994, the Nigerian government initiated water control measure in Kainji Lake Basin, enlightenment campaign was carried out to determine knowledge level of the fisher-folks concerning the water hyacinth infestation on the lake and the associated problems, deciding on plan of action towards controlling and eliminating the weed on lake Kainji and enlightening fisherfolks on additional scientific information on the characteristics of the weed (Alamu et al., 2000). The enlightenment campaign attracted many stakeholders who were greatly involved in the physical removal of the weed from the beaches. The campaign contributed in no small measure in increasing the knowledge level of the local people. Organized training sessions were conducted for members of the local communities and Technical Staff who were actually involved in the control program.

It is necessary to include the monitoring of other biological communities in reservoir, to evaluate if adopted management options have positive or negative effects on the water body. It is also desirable to include baseline data collection in monitoring Programs. In Kainji lake, monitoring team was set up by the National Institute for Freshwater Fisheries Research and the Nigerian German Kainji Fisheries Promotion Project were responsible for monitoring the extent of the clearing activities in the communities and liaising with fishing communities on progress made concerning other methods by the Nigerian government. A remarkable achievement was made with co-operation of the fishing communities.

\section{METHODS OF AQUATIC WEED CONTROL}

The aquatic weed control is carried out using these methods; Physical or mechanical control; Biological control and Chemical control. These methods have been summarized in Table 4 below.

\section{RECOMMENDATIONS}

According to Madsen 2005 Components of a plan includes: Prevention, Problem Assessment, Project Management, Education, Monitoring, Site- or problemspecific management goals, and Evaluation. Prevention seeks to reduce the influx of new invaders into the resources, and respond rapidly once they are found. Problem assessment is to quantify the distribution and abundance of the target plant and its impacts on the resource.

Project Management includes tracking available resources to fight the problem, including funds and labor. Education involves informing both the resource agency and the public in the problem and potential solutions.

A monitoring component tracks the general condition of the resource in both biotic and abiotic attributes, to detect other changes associated with the resource. a Site- or problem-specific goal addresses the 
Uka et al.: Distribution of major aquatic weeds in Nigeria inland waters.

Table 3 - Distribution of aquatic weeds in major inland water bodies found in the hydrological areas.

\begin{tabular}{|c|c|c|}
\hline RIVER BASINS /STATE & Aquatic weeds & Affected/Infested areas \\
\hline $\begin{array}{l}\text { Upper/Lower Niger River Basin } \\
\text { Niger,Abuja,Kaduna, } \\
\text { Plateau,Nassarawa, } \\
\text { Benue,Kogi\& Kwara }\end{array}$ & $\begin{array}{l}\text { Echhornia crassipes, } \\
\text { Nymphea lotus } \\
\text { Pistia stratiotes, Cattail } \\
\text { Ceratophyllum demersum } \\
\text { Salvinia nymphella, } \\
\text { Vossia cuspidate } \\
\text { Typha latifolia } \\
\text { Phragmite karka } \\
\text { Echinochloa spp }\end{array}$ & $\begin{array}{l}\text { Kaduna river, River Niger, Lake Kainji lake, } \\
\text { Shiroro lake, Tagwai dam,Kangim } \\
\text { dam,River Benue,,River Katsina- } \\
\text { Ala,Swamps, Reservoirs,Oshin,Afelele, } \\
\text { Awon,River/Benue confluence }\end{array}$ \\
\hline $\begin{array}{l}\text { Upper/Lower Benue River and } \\
\text { Chad Basin } \\
\text { Adamawa } \\
\text { Bauchi } \\
\text { Gombe } \\
\text { Borno } \\
\text { Taraba } \\
\text { Yobe }\end{array}$ & $\begin{array}{l}\text { Typha latifolia } \\
\text { Eichhornia crassipes } \\
\text { Nymphea lotus } \\
\text { Pistia stratiotes }\end{array}$ & $\begin{array}{l}\text { Kiri dam, Lake Geriyo,River Benue, River } \\
\text { Gongola,Lake Chad,Alau } \\
\text { reservoir.Dadinkowa dam, Canal of lake } \\
\text { Balanga,Gubi dam }\end{array}$ \\
\hline $\begin{array}{l}\text { Hadejia/Jama'are Sokoto-Rima } \\
\text { River Basin } \\
\text { Kebbi } \\
\text { Sokoto } \\
\text { Zamfara } \\
\text { Katsina } \\
\text { Kano } \\
\text { Jigawa }\end{array}$ & $\begin{array}{l}\text { Azolla sp, } \\
\text { Polygonium lanigerium, } \\
\text { Mimosa pigra, } \\
\text { Alternanitaera sessilis, } \\
\text { Echinochloa spp, } \\
\text { Ludwigia spp, } \\
\text { Ceratophyllum demersum, } \\
\text { Scrippus spp, } \\
\text { Pistia stratiotes } \\
\text { Polygonium spp } \\
\text { Commelina benghalensis } \\
\text { Typha latifolia } \\
\text { Nymphea lotus }\end{array}$ & $\begin{array}{l}\text { River Argungu,Kwari Lake, } \\
\text { Lake Natu, Jankara reservoir } \\
\text { Ruwan Kanya Reservoir } \\
\text { Kunde Reservoir, } \\
\text { Hadejia Jamare'are wetlands }\end{array}$ \\
\hline $\begin{array}{l}\text { Osun,Ogun and Owena River } \\
\text { Basin }\end{array}$ & $\begin{array}{l}\text { Eichhornia crassipes } \\
\text { Nymphea lotus } \\
\text { Pistia stratiotes } \\
\text { Ceratophyllum demersum } \\
\text { Leersia hexandra } \\
\text { Ludwigia stolonifera } \\
\text { Ipomea aquatica } \\
\text { Cyperus exaltatus } \\
\text { Water fern } \\
\text { Water lettuce }\end{array}$ & $\begin{array}{l}\text { Warri river,Ethiope river, Ase river, Niger } \\
\text { river,Gelegele river Siloko river ,Ofunama } \\
\text { river, Ikoro river,Ikpoba } \\
\text { reservoir,Ogbese/Owa river, Ovia/lgueben } \\
\text { dam } \\
\text { Oghodegbeda dam } \\
\text { River Tolita, } \\
\text { Oluwa,Siluko,Alape,Ofara and Apata rivers } \\
\text { Okubakuku, Adelesimo, Obenta, Legha } \\
\text { Aiyetoro Western Mahin and Biobu creeks. } \\
\text { Ede, Esa, Odo, Oke Ede, Iwo reservoirs. } \\
\text { Okinni Owala, Osun, Oba, Otin, Asejire and } \\
\text { Oora swamp. } \\
\text { Eleyele reservoir, Ere creek, Yewa river, } \\
\text { Akere reservoir,Ogun,Oyan,Iro/Moloki and } \\
\text { Okomayo rivers,Lekki lagoon,Badagry } \\
\text { creek, Lagos lagoon, Lagos Harbour,Omu } \\
\text { creek, Epe,Five Cowrie,Epe lagoon and } \\
\text { Abessan river. }\end{array}$ \\
\hline $\begin{array}{l}\text { Anambra,Imo,Niger Delta and } \\
\text { Cross River Basin }\end{array}$ & $\begin{array}{l}\text { Eichhornia crassipes, Water } \\
\text { lettuce, Water fern, Water lily, } \\
\text { Typha latifolia, Ipomea aquatica }\end{array}$ & $\begin{array}{l}\text { River Niger,Obanliku reservoir,Obudu } \\
\text { reservoir and Blue river }\end{array}$ \\
\hline
\end{tabular}

Source: NIFFR (2002) 
Table 4 - Qualitative rating of level of aquatic weeds infestation in Nigeria inland waters.

\begin{tabular}{|c|c|c|c|c|c|}
\hline \multirow[t]{2}{*}{ STATE } & \multicolumn{5}{|c|}{ " TYPES OF WEEDS } \\
\hline & EC & PS & NL & TA & OW \\
\hline Abia & +++ & +++ & +++ & + & \\
\hline Adamawa & +++ & +++ & ++ & +++ & \\
\hline Akwa-lbom & + & + & ++ & + & \\
\hline Anambra & +++ & ++ & ++ & + & + \\
\hline Bauchi & - & ++ & ++ & +++ & \\
\hline Bayelsa & ++ & ++ & ++ & + & \\
\hline Benue & +++ & ++ & + & ++ & \\
\hline Borno & - & +++ & - & ++++ & \\
\hline C/River & ++ & +++ & ++ & + & \\
\hline Delta & ++++ & ++ & ++ & ++ & ++ \\
\hline Ebonyi & - & +++ & ++ & - & \\
\hline Edo & ++++ & ++ & ++ & ++ & ++ \\
\hline Ekiti & +++ & ++ & ++ & + & + \\
\hline Enugu & - & ++ & + & + & \\
\hline FCT,Abuja & ++ & +++ & ++ & ++ & \\
\hline Gombe & ++ & +++ & +++ & +++ & \\
\hline Imo & +++ & ++ & ++ & + & \\
\hline Jigawa & - & ++ & ++ & ++++ & \\
\hline Kaduna & ++ & ++ & ++ & ++ & \\
\hline Kano & +++ & ++ & ++ & ++++ & \\
\hline Kebbi & ++++ & + & + & ++ & ++ \\
\hline Kogi & +++ & ++ & ++ & ++ & \\
\hline Kwara & ++++ & +++ & ++ & ++ & \\
\hline Lagos & ++++ & ++ & ++ & ++ & \\
\hline Nassarawa & - & ++ & ++ & +++ & \\
\hline Niger & ++++ & +++ & ++ & ++ & \\
\hline Ogun & ++++ & ++ & ++ & ++ & ++ \\
\hline Ondo & +++ & + & ++ & + & + \\
\hline Osun & ++ & - & ++ & + & +++ \\
\hline Oyo & ++ & ++ & ++ & +++ & + \\
\hline Plateau & + & + & + & + & ++ \\
\hline Rivers & ++ & & & & \\
\hline Sokoto & ++ & ++ & ++ & +++ & ++ \\
\hline Taraba & +++ & +++ & +++ & +++ & \\
\hline Yobe & - & ++ & + & +++ & \\
\hline Zamfara & - & ++ & ++ & +++ & \\
\hline
\end{tabular}

Key: - = Absent; + = Rare; + + = Slight; + ++ = Moderate; ++ ++ = Extensive

EC $=$ Eichhornia crassipes $\mathbf{P S}=$ Pistia stratiotes $\mathbf{T A}=$ Typha latifolia $\mathbf{O W}=$ Other weeds Source: NIFFR (2002)

management of target species based on a specific site basis, rather than attempting to find a single solution to the target plant problem through time for all locations.

Aquatic weeds infestation in Nigeria waters is increasing geometrically. This can be attested to considering its infestation in almost all the streams, lakes, rivers and reservoirs. Government intervention is basically during critical situations. Therefore adequate budgetary provisions should be made and institutions involved in management and control of aquatic weeds strengthened.

Our freshwater is a public amenity and as such should be in harmony with the environment. None of the control methods will guarantee the success of aquatic weed management. An integrated approach, including utilization of weeds as a resource is a way of protecting the quality of the environment. Therefore to develop more effective ways of managing aquatic weeds, better knowledge of biological, ecological and economical aspects of aquatic macrophytes are needed.

\section{REFERENCES}

Aquatic Ecosystem Restoration Foundation (AERF). 2005. Aquatic Plant Management: Best Management Practices in Support of Fish and 
Uka et al.: Distribution of major aquatic weeds in Nigeria inland waters.

Table 5 - Summary of management options for the control of aquatic weeds.

\begin{tabular}{|c|c|c|c|c|}
\hline $\begin{array}{l}\text { Management } \\
\text { trategy }\end{array}$ & Description & Advantages & Disadvantages & $\begin{array}{c}\text { Plant species } \\
\text { Response }\end{array}$ \\
\hline Hand pulling & $\begin{array}{l}\text { Direct hand pulling or } \\
\text { use of hand tools }\end{array}$ & $\begin{array}{l}\text { Completely removes } \\
\text { nuisance plants }\end{array}$ & $\begin{array}{l}\text { Can be labor } \\
\text { intensive depending } \\
\text { on size to be treated }\end{array}$ & $\begin{array}{l}\text { Very effective in } \\
\text { localised areas. }\end{array}$ \\
\hline Draw down & $\begin{array}{l}\text { Lowering water level } \\
\text { may be manipulated } \\
\text { in the fall to allow } \\
\text { sediments and plants } \\
\text { to freeze, and dry } \\
\text { out. }\end{array}$ & $\begin{array}{l}\text { Inexpensive, very } \\
\text { effective, moderate- } \\
\text { term }\end{array}$ & $\begin{array}{l}\text { Can have severe } \\
\text { environmental } \\
\text { impacts. will effect all } \\
\text { plant species and } \\
\text { wild life, may effect } \\
\text { access to water } \\
\text { supplies increase } \\
\text { post-drawdown } \\
\text { nutrient levels and } \\
\text { turbidity. }\end{array}$ & $\begin{array}{l}\text { Selective based on } \\
\text { timing. Effective on } \\
\text { evergreen perennials, } \\
\text { Less effective on } \\
\text { herbaceous } \\
\text { perennials }\end{array}$ \\
\hline Benthic Barriers & $\begin{array}{l}\text { Natural or synthetic } \\
\text { materials to cover } \\
\text { plant }\end{array}$ & $\begin{array}{l}\text { (Black screened } \\
\text { secured to lake } \\
\text { bottom like a carpet) } \\
\text { Blocks sunlight and } \\
\text { prevents growth, } \\
\text { impedes } \\
\text { fragmentation. }\end{array}$ & $\begin{array}{l}\text { High maintenance, } \\
\text { Effects non-target } \\
\text { plant and soil below } \\
\text { barrier. }\end{array}$ & $\begin{array}{l}\text { Nonselective, plant } \\
\text { mortality within one } \\
\text { month underneath } \\
\text { barrier. }\end{array}$ \\
\hline Floating nets & $\begin{array}{l}\text { Total removal of } \\
\text { plants and associated } \\
\text { sediments. }\end{array}$ & $\begin{array}{l}\text { Enclose small area } \\
\text { cover or inlet) to } \\
\text { inhibit spread of plant } \\
\text { fragments }\end{array}$ & $\begin{array}{l}\text { Requires proper } \\
\text { anchor, can impede } \\
\text { boating, swimming } \\
\text { and fish movement }\end{array}$ & \\
\hline Dredging & $\begin{array}{l}\text { Total removal of } \\
\text { plants and associated } \\
\text { sediments }\end{array}$ & $\begin{array}{l}\text { Creates deeper } \\
\text { water, very long-term } \\
\text { results }\end{array}$ & $\begin{array}{l}\text { Very expensive, } \\
\text { alters lake ecology, } \\
\text { will impact all plants } \\
\text { and wildlife, may } \\
\text { cause water quality } \\
\text { problems }\end{array}$ & $\begin{array}{l}\text { Often creates large } \\
\text { areas of lake } \\
\text { tempora free of } \\
\text { plants, not selective. }\end{array}$ \\
\hline Chemical control & $\begin{array}{l}\text { Control of herbicides } \\
\text { by use of herbicides }\end{array}$ & $\begin{array}{l}\text {-Can control large } \\
\text { areas, } \\
\text {-Chemical may be } \\
\text { specific to plant } \\
\text { species, } \\
\text {-Results may be seen } \\
\text { rapidly and one } \\
\text { application may work } \\
\text { for } 1-3 \text { years, but } \\
\text { more may be } \\
\text { required. }\end{array}$ & $\begin{array}{l}\text { High initial cost; } \\
\text { requires state permit; } \\
\text { use of water body for } \\
\text { swimming and } \\
\text { drinking often limited } \\
\text { for period of time } \\
\text { after application. }\end{array}$ & $\begin{array}{l}\text { Selective } \\
\text {-Systemic growth } \\
\text { regulator } \\
\text {-Non selective }\end{array}$ \\
\hline Biological Controls & $\begin{array}{l}\text { Exploitation of living } \\
\text { organism or their } \\
\text { products to reduce or } \\
\text { prevent the growth } \\
\text { and reproduction of } \\
\text { weeds }\end{array}$ & $\begin{array}{l}\text { Introduction of } \\
\text { natural prey (insects, } \\
\text { fish) into lake to } \\
\text { control plant } \\
\text { population; often } \\
\text { highly specific for } \\
\text { plant target }\end{array}$ & $\begin{array}{l}\text {-Introduction of new } \\
\text { species may be } \\
\text { problematic (or } \\
\text { unethical); } \\
\text {-Highly experimental } \\
\text { and may require } \\
\text { permit. }\end{array}$ & $\begin{array}{l}\text { Reduction in plant } \\
\text { mass, } \\
\text {-Reproduction and } \\
\text { density due to leaf, } \\
\text { stem, flower and root } \\
\text { feeding. }\end{array}$ \\
\hline
\end{tabular}

Source: Lancar \& Kraker (2002) and Madsen (1997 and 2000)

Wildlife Habitat. Aquatic Ecosystem Restoration Foundation, Lansing, MI. 78pp.

Lancer, L. \& Krake, K. 2002. Aquatic Weed and their Management. International Commission on Irrigation and Drainage. 65pp.
Madsen, J.D. 1997. Methods for management of nonindigenous aquatic plants. In: Assessment and Management of plant invasions. Luken, J.O. \& Thieret, J.W. (eds). Springer, New York, N.Y. pp. $145-171$. 
Madsen, J.D. 2000. Advantages and disadvantages of aquatic plant management techniques: Part II Mechanical and physical management techniques. Lakeline 20(1):22-34.

Madsen, J.D. 2005. Developing Plans for Managing Invasive Aquatic Plants in Mississippi Water Resources. Mississippi State University and Water Resources Institute, Mississippi State, MS. Pp 7.

Madsen, J. 1999. Point intercept and line intercept methods for aquatic plant management. Aquatic Weed Control Technical Note MI-02 February 1999.15pp
Mitchell D.S. 1985. African Aquatic weeds and their management. In: The ecology and management of African wetland vegetation. P. Denny (ed). Dr. N. Junk Dordrecht. The Netherlands. p177-202.

National Institute for Freshwater Fisheries Research (NIFFR), 2002. National Surveys of Infestation of Water Hyacinth, Typha Grass and other noxious weed in water bodies of Nigeria. NIFFR Occasional Paper No.5. 52pp

Uka,U.N. 2006. Impact of Water hyacinth infestation on water quality and Plankton diversity in Awba reservoir, Ibadan-Nigeria. Unpublished M.Sc. Project of the University of Ibadan, Ibadan. 87pp. 